\title{
SPINAL CORD INJURIES DUE TO DIVING
}

\author{
H. L. Frankel, M.B., F.R.C.P., F. A. Montero, M.D. and \\ P. T. PENNY, M.B., B.S., M.R.C.S., L.R.C.P. ${ }^{1}$ \\ National Spinal Injuries Centre, Stoke Mandeville Hospital, Aylesbury, Bucks. and \\ 1 Medical Officer, Amateur Swimming Association
}

Key words: Tetraplegia; Spinal cord injuries; Diving.

\section{Introduction}

THE relative frequency of tetraplegia and tetraparesis due to diving was shown by Frankel et al. (1969). Burke (1972) described the incidence in the State of Victoria, Australia, and also discussed the mechanisms of injury; Burke (1978) was able to analyse a hundred cases of tetraplegia due to diving admitted between the years 1955-77. An increasing awareness of and interest in the subject is shown in papers by Albrand and Corkhill (1976), Kewalramani and Kraus (1977) and Scher (1978).

\section{Methods and Results}

Notes of all patients injured in diving accidents who were admitted to the National Spinal Injuries Centre, Stoke Mandeville Hospital since its founding in I 944 until the end of 1977 were examined. A total of I50 patients, I 42 male and 8 females were admitted. The age structure of the patients admitted is shown in Fig. I. The vertebral body or bodies shown to be involved are illustrated in Table I. The expected preponderance of $\mathrm{C}_{5}$ on $\mathrm{C} 6$ dislocations and fracture dislocations was found, we were surprised to find four patients with upper dorsal lesions. On discharge from hospital 79 patients had complete lesions and $7 \mathrm{I}$ had incomplete lesions. The type of water into which they dived was swimming pool 48 , sea 65 , river 21 , lake 3 , not known 13 . The year in which the patients were injured is shown in Fig. 2. This shows an apparent 'epidemic' in the mid I96os followed by a dramatic decline which has now relatively levelled off. In order to find out how this decline arose we have examined four groups of patients separately: I. British residents injured in Britain (64);2. British residents injured while on holiday abroad (I6); 3. British Servicemen injured while serving abroad (29); 4. Foreign residents injured outside Great Britain and admitted for treatment at a late stage as private patients (4I). Their occurrence over the years is shown in Fig. 2 which shows that much of the apparent epidemic of the mid I96os was due to large numbers of British Servicemen injured abroad in those years. Foreign patients were self selected and of no value in epidemiological studies. The large number of British Servicemen injured abroad were a passing phenomenon of the period between 1953 and 1964 and the British civilians injured abroad are small in number. We have, therefore, analysed in further detail only the 64 British residents injured in Britain. One of the purposes of this analysis was to see whether the intensive safety campaign conducted by one of us (P.T.P.) in 1965 and I 966 which concentrated on swimming pool safety had any effect. The pattern 
of injury in swimming pools, sea and rivers is shown in Fig. 3, this does not show a convincing diminution of swimming pool accidents. Table II shows approximately half the cases occurred by diving into the shallow end of a swimming pool.

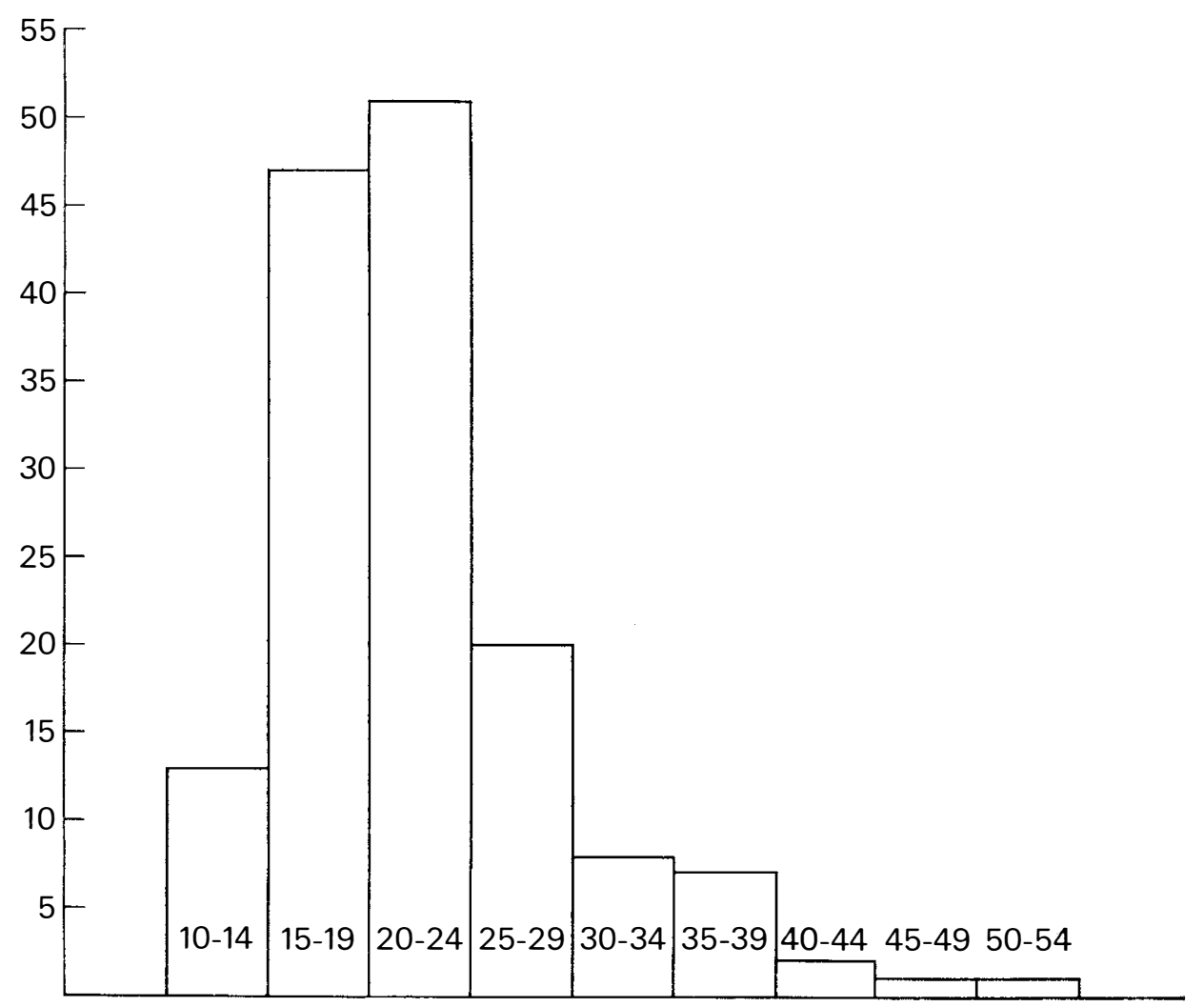

Age in years

FIG. I

Age structure of patients

TABLE I

Bony Injury

\begin{tabular}{lr}
\hline $\mathrm{C}_{2}-3$ & I \\
$\mathrm{C}_{3}-4$ & 2 \\
C4 & 4 \\
C4-5 & 20 \\
C5 & I4 \\
C5-6 & 59 \\
C6 & II \\
C6-7 & 23 \\
C7 & 4 \\
C7-TI & 2 \\
Thoracic & 4 \\
No bony injury & 2 \\
Not known & 4 \\
\hline
\end{tabular}




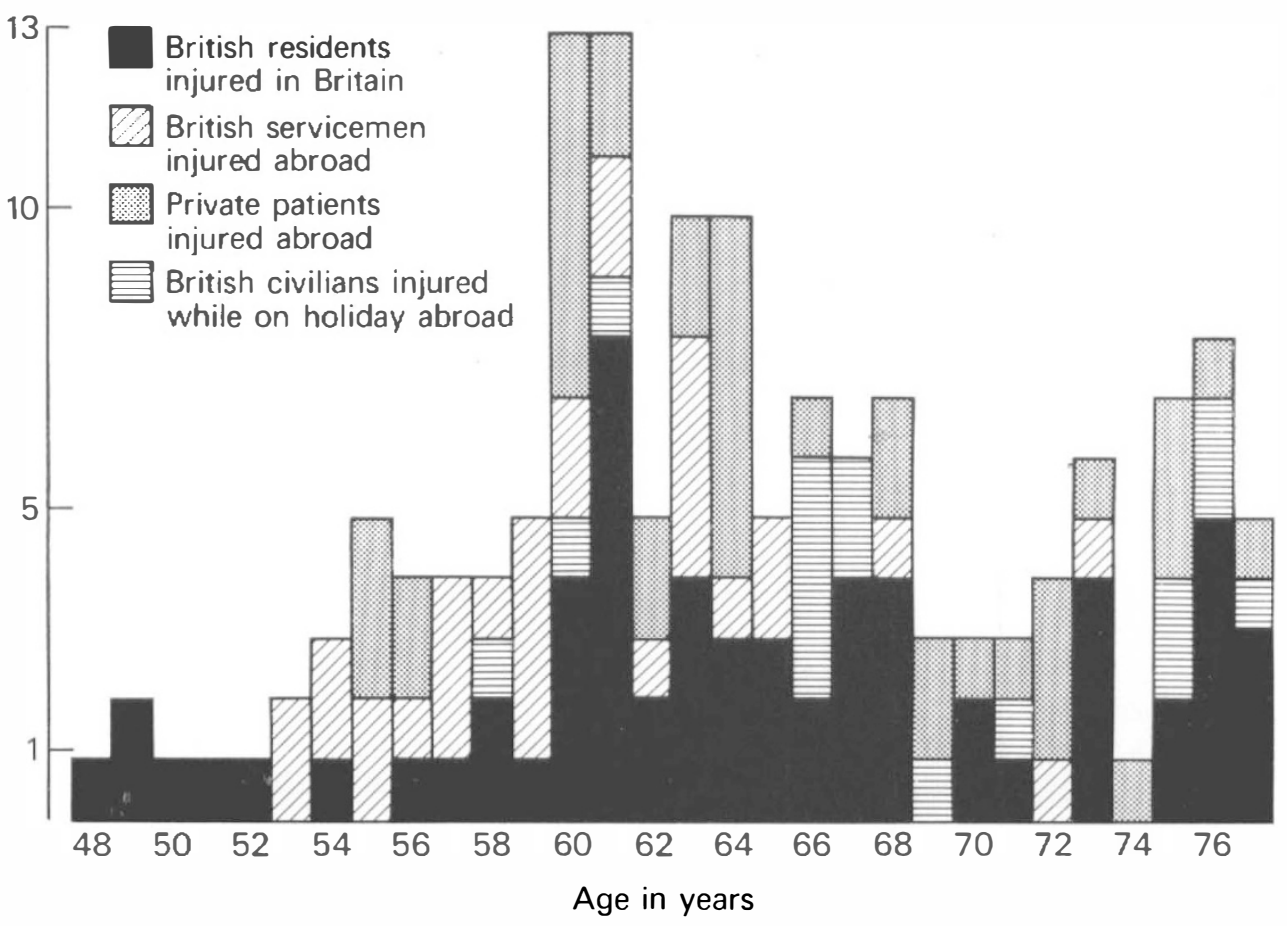

FIG. 2

Diving accidents from I948 to 1976.

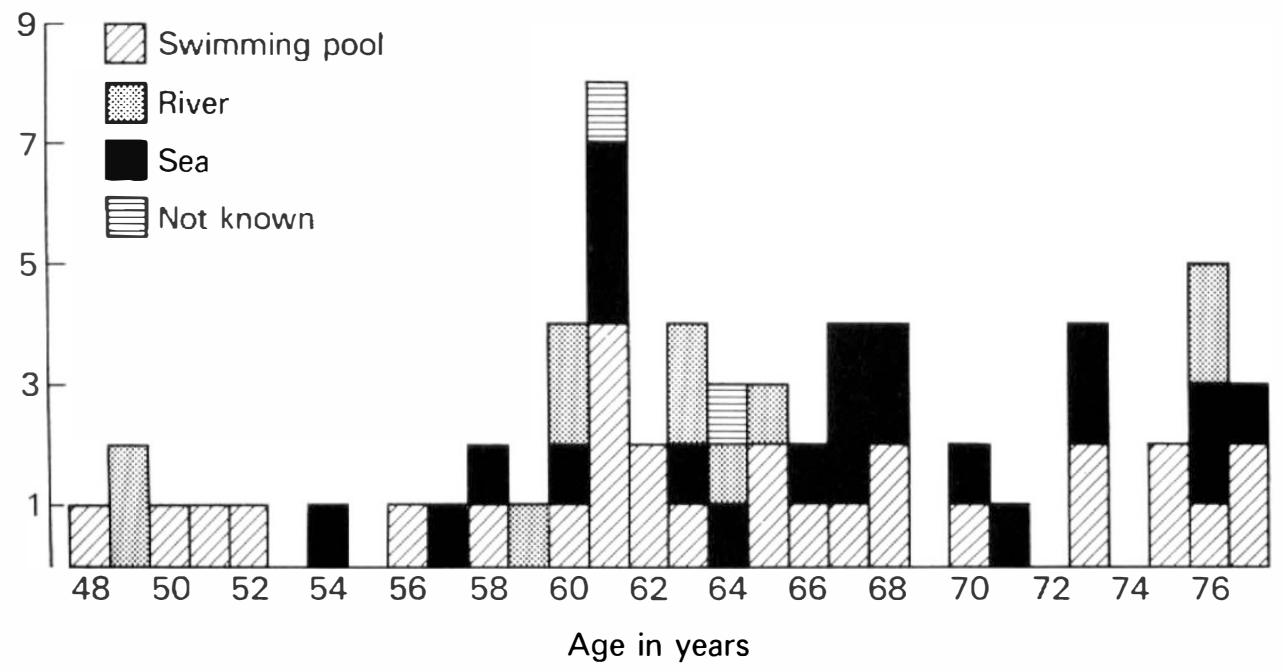

FIG. 3

Types of injury in Britain over the years. 
TABLE II

\begin{tabular}{cc}
\hline Swimming Pool Accidents in the United Kingdom \\
\hline Shallow end & I3 \\
Deep end (diving board) & 6 \\
Hit edge of pool & I \\
Hit by another diver & 2 \\
Found floating on pool & I \\
Not known & 4 \\
Total & 28 \\
\hline
\end{tabular}

\section{Discussion}

The tragedy of tetraplegia due to diving has not been eliminated by previous publicity relating to swimming pools. Although injuries caused by diving from a height into the 'deep' end of swimming pools has been virtually eliminated from Britain by the regulations agreed by the Federation International Natation Association (see appendix), injuries due to diving into the shallow end of swimming pools have continued and in two cases were due to children who were being taught to dive. Two thirds of our cases were due to diving into the sea or rivers and the general public seem to be unaware of the risks of diving into unknown depths of sea water and the risks of striking submerged objects. The possibility that deaths reported as drowning were in fact due to tetraplegia followed by drowning was mentioned by Burke (1972) and it is probable that many such cases occur.

Notices in swimming pools and popular beaches are either not read or widely ignored. We would suggest that the most effective way of teaching the population about the dangers of diving into shallow water would be at the time when they are learning to swim. In Britain the majority of children learn to swim at school or in public swimming pools. We propose to initiate an educational campaign in Great Britain which we hope will reach all children at a time when they are learning to swim. This could be reinforced by dramatic warnings on television shown in the Summer.

\section{SUMMARY}

One hundred and fifty patients with spinal cord lesions due to diving accidents were admitted to Stoke Mandeville Hospital between 1944-77. Most of the patients were young men, 65 had dived into the sea, 48 into swimming pools, $2 \mathrm{I}$ into rivers and 3 into lakes. Injuries due to diving into the deep end of swimming pools appear to have been eliminated in Great Britain but injuries due to diving into the shallow end of swimming pools and into the sea continue to occur. The public need further education about the dangers of diving.

\section{RÉSUMÉ}

I 50 malades de lesions traumatique de la moelle épinière ont été traite à Stoke Mandeville Hospital en la periode 1944-I977.

La majorité était des jeunes hommes.

Les lesions étaient du aux plongeons de mer: 65

Ptongeons de piscine: 48

c) riviere: 2 I

I longeons de lac: 3

I $8 / 2-D$ 
Les injures de plongeon dans la profondeur de la piscine semblent avoir disparu; tandis que l'on continue à voir des injures de plongeon dans le bas fond de la piscine et de la mer.

Le public a besoin de plus d'éducation au sujet des dangers des accidents de plongeon.

\section{ZUSAMMENFASSUNG}

I50 Patienten mit Rückgratsverletzungen durch Tauchunfälle wurden in den Jahren 1944-I977 im Stoke Mandeville Hospital behandelt. Bei den meisten Patienten handelte es sich im junge Männer; 65 von ihnen waren ins Meer gesprungen, 48 in Schwimmbecken, $2 \mathrm{I}$ in Flüsse und 3 in Seen. Verletzungen durch Sprünge in den tief en Teil eines Schwimmbeckens scheinen in Grossbritannien nicht mehr vorzukommen, wohl aber Verletzungen bei Sprüngen in den flachen Teil von Schwimmbecken und ins Meer. Die Öffentlichkeit muss weiterhin auf die Gefahren beim Tauchen hingewiesen werden.

Acknowledgement. The authors would like to express their gratitude to Miss BizzamSchmid of Boston, U.S.A. for her assistance.

\section{REFERENCES}

Albrand, O. W. \& CoRKhILl, G. (I976). Broken necks from diving accidents: a summer epidemic in young men. Am. F. Sports. Med., 4, I07-I IO.

Burke, D. C. (I972). Spinal cord injuries from water sports. Med. F. Aust., 2, I I90-I I94. BuRKe, D. C. (1978). Diving injury resulting in tetraplegia. Med. F. Aust., I, I 7 I.

FRANKEL, H. L., et al. (I969). The value of postural reduction in the initial management of closed injuries of the spine with paraplegia and tetraplegia. Part I. Paraplegia, 7, I79-I92.

Kewalramani, L. S., Kraus, J. F. (1977). Acute spinal cord lesions from divingepidemiological and clinical features. West. F. Med., 126, 353-361.

Scher, A. T. (I978). Spinal cord injuries due to diving accidents. F. Sports. Med. Phys. Fitness., 18, 67-70.

\section{APPENDIX}

\begin{tabular}{|c|c|c|c|c|c|c|c|c|}
\hline \multirow[b]{2}{*}{ A } & \multicolumn{8}{|c|}{ Recreational Diving (Firm Board) } \\
\hline & Board height from water & $\mathrm{I} \mathrm{m}$ & I $\mathrm{m}$ & $2 \mathrm{~m}$ & $2 \mathrm{~m}$ & $3 \mathrm{~m}$ & $3 \mathrm{~m}$ & $5 \mathrm{~m}$ \\
\hline B & Board length & 0.75 & $\mathrm{I} \cdot 75$ & 0.75 & $\mathrm{I} \cdot 75$ & 0.75 & $\mathrm{I} \cdot 75$ & $5 \cdot 0$ \\
\hline $\mathrm{C}$ & Board width & 0.75 & 0.75 & 0.75 & 0.75 & 0.75 & 0.75 & $2 \cdot 0$ \\
\hline $\mathrm{D}$ & Depth of water at plummet & $2 \cdot 6$ & $2 \cdot 6$ & $3 \cdot 0$ & $3 \cdot 0$ & 3.25 & $3 \cdot 25$ & $3 \cdot 8$ \\
\hline $\mathrm{E}$ & Distance depth D maintained & & & & & & & \\
\hline $\mathrm{F}$ & $\begin{array}{l}\text { forward } \\
\text { Distance depth D maintained to }\end{array}$ & $3 \cdot 0$ & $4 \cdot 0$ & $3 \cdot 0$ & $4 \cdot 0$ & $3 \cdot 5$ & $4 \cdot 5$ & $6 \cdot 0$ \\
\hline & & $2 \cdot 2$ & $2 \cdot 2$ & $2 \cdot 4$ & $2 \cdot 4$ & $2 \cdot 6$ & $2 \cdot 6$ & $3 \cdot 0$ \\
\hline G & Clearance forward & $4 \cdot 5$ & $5 \cdot 5$ & $5 \cdot 5$ & $6 \cdot 5$ & $6 \cdot 5$ & $7 \cdot 5$ & $10 \cdot 25$ \\
\hline $\mathrm{H}$ & Clearance to sides & $2 \cdot 5$ & $2 \cdot 5$ & $3 \cdot 0$ & $3 \cdot 0$ & $3 \cdot 5$ & $3 \cdot 5$ & $3 \cdot 8$ \\
\hline I & Distance to adjacent board & $2 \cdot 5$ & $2 \cdot 5$ & $2 \cdot 5$ & $2 \cdot 5$ & $2 \cdot 5$ & $2 \cdot 5$ & $2 \cdot 5$ \\
\hline $\mathrm{J}$ & Clearance behind & $I \cdot 25$ & $I \cdot 25$ & $I \cdot 25$ & $\mathrm{I} \cdot 25$ & $I \cdot 25$ & $\mathrm{I} \cdot 25$ & $\mathrm{I} \cdot 25$ \\
\hline $\mathrm{K}$ & Clearance behind board to wall & 0.8 & 0.8 & 0.8 & 0.8 & 0.8 & 0.8 & 0.8 \\
\hline $\mathrm{L}$ & Clearance overhead & $3 \cdot 0$ & $3 \cdot 0$ & $3 \cdot 0$ & $3 \cdot 0$ & $3 \cdot 0$ & $3 \cdot 0$ & $3 \cdot 0$ \\
\hline
\end{tabular}

